\title{
The Federal Reserve's Commercial Paper Funding FaCiLity
}

\section{InTRODUCTION}

$\mathrm{T}$ he commercial paper market experienced considerable strain in the weeks following Lehman Brothers' bankruptcy on September 15, 2008. The Reserve Primary Fund-a prime money market mutual fund with $\$ 785$ million in exposure to Lehman Brothers- "broke the buck" on September 16, triggering an unprecedented flight to quality from high-yielding to Treasury-only money market funds. These broad investor flows within the money market sector severely disrupted the ability of commercial paper issuers to roll over their short-term liabilities.

As redemption demands accelerated, particularly in highyielding money market mutual funds, investors became increasingly reluctant to purchase commercial paper, especially for longer dated maturities. As a result, an increasingly high percentage of outstanding paper had to be refinanced each day, interest rates on longer term commercial paper increased significantly, and the volume of outstanding paper declined sharply. These market disruptions had the potential to constrain the economic activities of commercial paper issuers. Indeed, a large share of outstanding commercial paper is issued or sponsored by financial intermediaries, and the difficulties they faced placing commercial paper further reduced their ability to meet the credit needs of businesses and households.

In light of these strains, the Federal Reserve announced the creation of the Commercial Paper Funding Facility (CPFF) on

Tobias Adrian is a vice president, Karin Kimbrough an assistant vice president, and Dina Marchioni a markets officer at the Federal Reserve Bank of New York. Correspondence: tobias.adrian@ny.frb.org
October 7, 2008, with the aim of supporting the orderly functioning of the commercial paper market. Registration for the CPFF began October 20, 2008, and the facility became operational on October 27. The CPFF operated as a lenderof-last-resort facility for the commercial paper market. It effectively extended access to the Federal Reserve's discount window to issuers of commercial paper, even if these issuers were not chartered as commercial banks. Unlike the discount window, the CPFF was a temporary liquidity facility that was authorized under section 13(3) of the Federal Reserve Act in the event of "unusual and exigent circumstances." It expired February 1, 2010. ${ }^{1}$

The goal of the CPFF was to address temporary liquidity distortions in the commercial paper market by providing a backstop to U.S. issuers of commercial paper. This liquidity backstop provided assurance to both issuers and investors that firms would be able to roll over their maturing commercial paper. The facility enabled issuers to engage in term lending funded by commercial paper issuance, which in turn enhanced the ability of financial intermediaries to extend crucial credit to U.S. businesses and households.

The CPFF did not address the solvency of issuing firms. Rather, the focus was on shielding the allocation of real economic investment from liquidity distortions created by the run on high-yielding money market instruments that had been

${ }^{1}$ Initially, the CPFF was set to expire on April 30, 2009, but it was extended to October 30 and subsequently to February 1, 2010.

The authors thank Sarah Bell, Marco Del Negro, Michael Fleming, Kenneth Garbade, Warren Hrung, Peter Kyle, James McAndrews, Patricia Mosser, Robert Patalano, and Joshua Rosenberg for substantial comments and contributions. Some sections of this paper are based on notes prepared by James McAndrews and Joshua Rosenberg in October 2008. Hoai-Luu Nguyen and Jordan Winder provided outstanding research assistance. The views expressed are those of the authors and do not necessarily reflect the position of the Federal Reserve Bank of New York or the Federal Reserve System. 
triggered by the bankruptcy of Lehman Brothers. The facility was explicitly designed to protect the Federal Reserve from potential credit losses. Issuance to the CPFF was either secured by collateral or subject to an additional surcharge, which was calibrated to protect the Federal Reserve from any potential credit losses.

This paper offers an overview of the Commercial Paper Funding Facility. We explain the economic role of the commercial paper market as a source of funding for various financial intermediaries. We briefly review the events surrounding the turmoil that led to the creation of the CPFF. Our study also presents operational details of the CPFF and documents its usage and effectiveness. In addition, we discuss the economics of the facility in the context of the financial system and in relation to the Federal Reserve's role as lender of last resort. Also considered are issues associated with the risk of moral hazard that have been raised following the launch of the CPFF.

\section{Background on the Commercial PAPer Market}

The commercial paper market is used by commercial banks, nonbank financial institutions, and nonfinancial corporations to obtain short-term external funding. There are two main types of commercial paper: unsecured and asset-backed.

Unsecured commercial paper consists of promissory notes issued by financial or nonfinancial institutions with a fixed maturity of 1 to 270 days, unless the paper is issued with the option of an extendable maturity. Unsecured commercial paper is not backed by collateral, which makes the credit rating of the originating institution a key variable in determining the cost of issuance.

Asset-backed commercial paper (ABCP) is collateralized by other financial assets and therefore is a secured form of borrowing. Historically, senior tranches of asset-backed securities (ABS) have served as collateral for ABCP. As such, $\mathrm{ABCP}$ is a financial instrument that has frequently provided maturity transformation: While the underlying loans or mortgages in the ABS are of long maturity (typically five to thirty years), $\mathrm{ABCP}$ maturities range between 1 and 270 days.

Institutions that issue $\mathrm{ABCP}$ first sell their assets to a bankruptcy-remote special-purpose vehicle (SPV). ${ }^{2}$ The SPV then issues the $\mathrm{ABCP}$, which is backed by the assets in the

\footnotetext{
${ }^{2} \mathrm{An}$ SPV is a legal entity created to serve a particular function-in this case, purchasing or financing specific assets. "Bankruptcy remoteness" refers to assets of an SPV being shielded from the bankruptcy of the sponsoring institution.
}

Chart 1

Outstanding Commercial Paper

and the Money Stock Measure (M1)

Billions of dollars

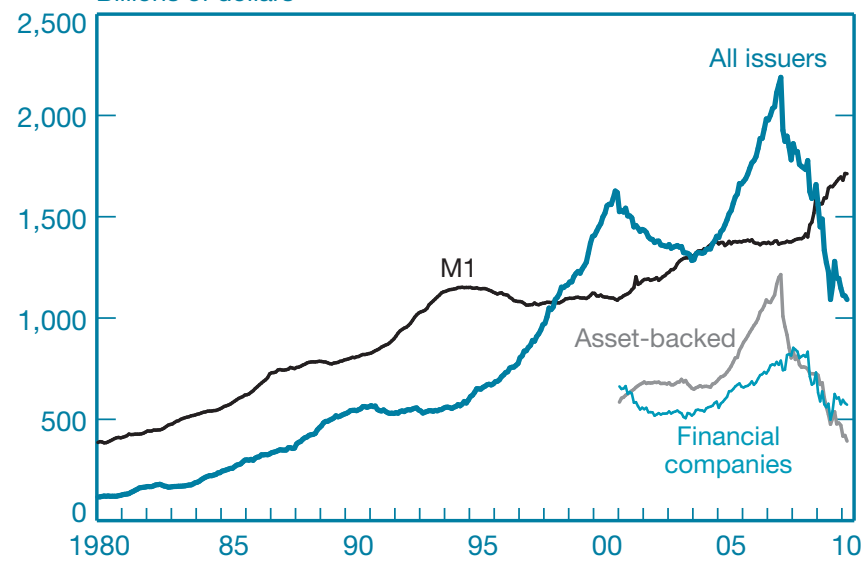

Source: Board of Governors of the Federal Reserve System.

vehicle and also by backup credit lines of the sponsoring institution. If the sponsoring institution enters bankruptcy, the assets of the SPV do not become part of the sponsor's pool of assets.

All commercial paper is traded in the over-the-counter market, where money market desks of securities broker-dealers and banks provide underwriting and market-making services. In the United States, commercial paper is cleared and settled by the Depository Trust Company (DTC). ${ }^{3}$

Commercial paper provides institutions with direct access to the money market. In traditional bank-intermediated financial systems, borrowing institutions obtain loans from commercial banks, which in turn are funded primarily by deposits. Since the early 1980s, however, the U.S. financial system has undergone a major transformation, as an everincreasing fraction of credit intermediation migrated from banks to financial markets.

One way to gauge the degree to which this process of disintermediation affected the commercial paper market is to compare outstanding commercial paper with the money stock. Commercial paper represented only 30 percent of the money stock measure (M1) in 1980. It overtook M1 in mid-1998 and, at its peak, was 60 percent larger than M1 in August 2007 (Chart 1). ${ }^{4}$ The sharp contractions of commercial paper in 2007 and 2008 led the ratio of commercial paper to M1 to fall

${ }^{3}$ DTC is a subsidiary of the Depository Trust and Clearing Corporation. See http://www.dtcc.com/.

${ }^{4} \mathrm{M} 1$ consists of: 1) currency outside the U.S. Treasury, Federal Reserve Banks, and the vaults of depository institutions; 2) travelers checks of nonbank issuers; 3) demand deposits; and 4) other checkable deposits. 
below 72 percent in the second half of 2009 , a fraction not seen since the mid-1990s.

The mix of unsecured commercial paper and ABCP in the market has varied considerably over the last few years, as ABCP represented more than 45 percent of the market between 2001 and 2007. The rise of ABCP is intertwined with the growth of securitization. Since 1998, financial intermediaries have increasingly relied on $\mathrm{ABCP}$ as a source of funding for assets warehoused for securitization. ${ }^{5}$ In the decade prior to the crisis, ABCP increased from $\$ 250$ billion in 1997 to more than $\$ 1$ trillion by 2007 (that is, from roughly 20 percent to as much as 50 percent of outstanding commercial paper), fueled by the considerable distribution of residential mortgage exposure through structured finance products.

Outstanding commercial paper peaked at a total market value of \$2.2 trillion in August 2007. At that time, ABCP accounted for more than 52 percent of the total market, while financial commercial paper accounted for an additional 38 percent and nonfinancial commercial paper approximately 10 percent. Between August 15, 2007, and September 15, 2008 , the market experienced a notable decline associated with mounting credit problems of ABCP collateral. The initial decline of outstanding ABCP is often used to date the beginning of the first wave of the 2007-09 financial crisis. ${ }^{6}$ As the deterioration of the U.S. housing market accelerated in the summer of 2007, the riskiness of the ABS used as collateral in ABCP transactions increased. As a result, ABCP issuers struggled to issue commercial paper.

Between September 2007 and January 2008, total assets of commercial banks grew unusually fast as many ABS that were previously funded in the ABCP market were moved from the balance sheets of ABCP issuers to those of commercial banks. As a result of a drying up of funding in the ABCP market, commercial banks started to fund the ABS in unsecured money markets, such as the Libor (London interbank offered rate), Eurodollar, and commercial paper markets, all of which would also become compromised at the peak of the crisis as credit risk reached extreme levels.

\subsection{Major Commercial Paper Issuers}

The Flow of Funds Accounts of the Federal Reserve provide an overview of issuers in the commercial paper market since the early 1980s (Chart 2). In the past decade, ABS issuers were the largest issuers of commercial paper, usually in the form of

\footnotetext{
${ }^{5}$ For an overview of asset-backed commercial paper, see Covitz, Liang, and Suarez (2009). Overviews of the securitization markets are provided by Adrian, Ashcraft, and Pozsar (2009) and Acharya and Schnabl (2010).

${ }^{6}$ For a comprehensive timeline of the financial crisis, see http:// timeline.stlouisfed.org/.
}

Chart 2

Commercial Paper Issuers

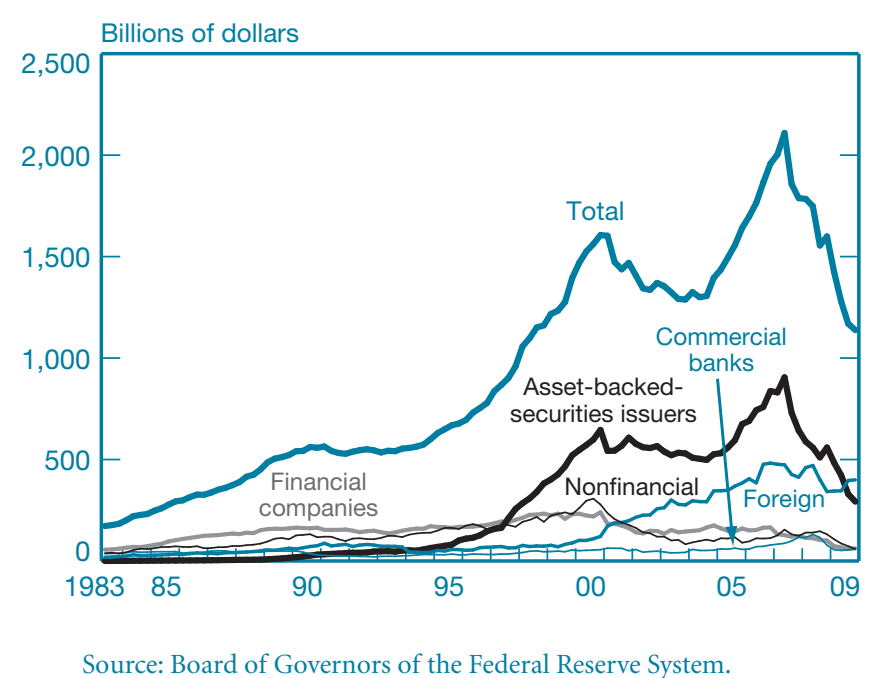

ABCP. Commercial paper funding of ABS stopped growing after Enron's bankruptcy in 2001, as changes in accounting and regulatory practices concerning off-balance-sheet entities required that additional capital be held against the entities on the balance sheet. ${ }^{7}$ At the end of 2003, capital regulation regarding off-balance-sheet conduits changed, and the growth of ABS-issued commercial paper resumed. Indeed, the growth in $\mathrm{ABS}$ issuance goes hand in hand with the growth of outstanding ABCP.

The second-largest issuers of commercial paper in recent years have been foreign issuers of U.S.-dollar-denominated paper, which include foreign banks and other financial institutions. Other issuers of commercial paper include finance companies, nonfinancial corporations, and commercial banks. For commercial banks, commercial paper issuance is relatively expensive; a combination of deposits—checking deposits, term deposits, or certificates of deposit-and borrowing in the federal funds market is usually a less expensive funding alternative than commercial paper (Chart 3), although a bank holding company might issue commercial paper more readily given the limited availability of deposits and financing that can be transferred from its commercial banks. ${ }^{8}$ However, commercial paper does provide a marginal source of funding to the commercial banking sector and, at times - and at least for certain issuers - commercial paper rates are actually lower than other money market rates, such as Eurodollar rates.

\footnotetext{
${ }^{7}$ For an overview of recent accounting changes concerning off-balance-sheet vehicles, see http://www.fasb.org/cs/ContentServer?c=FASBContent _C\&pagename=FASB\%2FFASBContent_C\%2FNewsPage\&cid=1176155633483.

${ }^{8}$ The relationship between commercial banks and affiliated subsidiaries is constrained by section 23A of the Federal Reserve Act; see http:// www.federalreserve.gov/aboutthefed/section23a.htm.
} 


\section{Chart 3}

Federal Funds, One-Month Libor, and Commercial Paper Rates

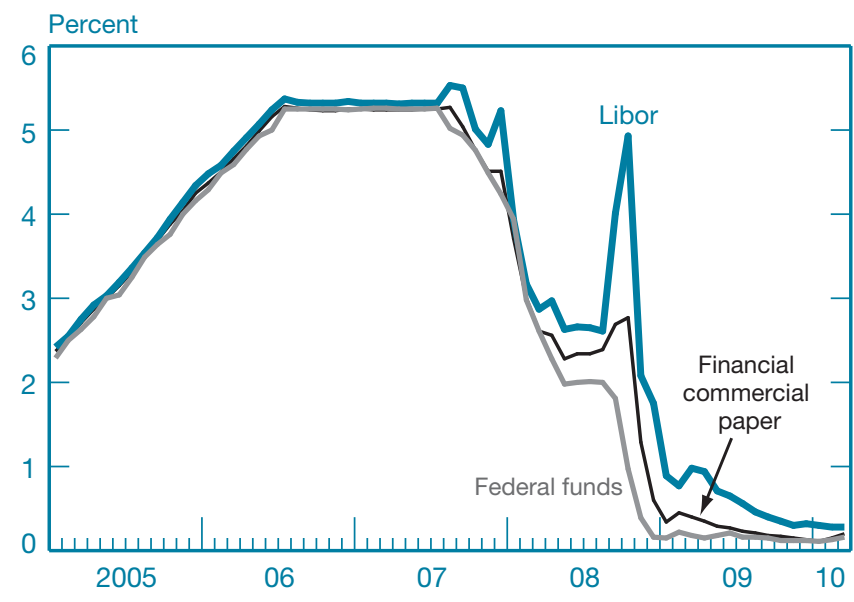

Source: Board of Governors of the Federal Reserve System.

Note: Libor is the London interbank offered rate.

As credit conditions deteriorated in the second half of 2007, many commercial banks took back onto their balance sheets obligations that were formerly held in off-balance-sheet vehicles and funded in the $\mathrm{ABCP}$ market. As a result, funding for these loans, mortgages, and securities migrated from the $\mathrm{ABCP}$ market to the unsecured interbank market, leading to a widening of the spread between Libor and the federal funds rate.

\subsection{Lenders in the Commercial Paper Market}

Commercial paper is held by many classes of investors (Chart 4). The largest share of ownership is by money market mutual funds, followed by the foreign sector, and then by mutual funds that are not money market mutual funds. Other financial institutions that hold commercial paper include nonfinancial corporations, commercial banks, insurance companies, and pension funds.

The creation of the Commercial Paper Funding Facility is closely tied to the operation of money market mutual funds. Money market funds in the United States are regulated by the Securities and Exchange Commission's (SEC) Investment Company Act of 1940. Rule 2a-7 of the Act restricts investments by quality, maturity, and diversity. Under this rule, money market funds are limited to investing mainly in highly rated debt with maturities of less than thirteen months. A fund's portfolio must maintain a weighted-average maturity of ninety days or less, and money market funds cannot invest more than 5 percent in any one issuer, except for government
Chart 4

Commercial Paper Holdings by Investor Class

Billions of dollars

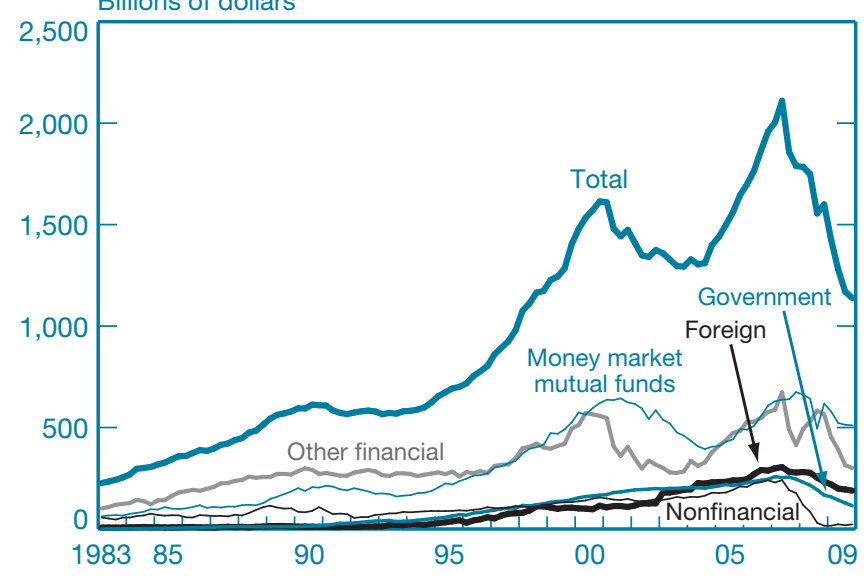

Source: Board of Governors of the Federal Reserve System.

securities and repurchase agreements (repos). Eligible money market securities include commercial paper, repos, short-term bonds, and other money market funds.

Money market funds seek a stable $\$ 1$ net asset value (NAV). If a fund's NAV drops below $\$ 1$, the fund is said to have "broken the buck." Money market funds, to preserve a stable NAV, must have securities that are liquid and have low credit risk. Between 1971—when the first money market fund was created in the United States-and September 2008, only one 2a-7 fund had broken the buck: the Community Bankers U.S. Government Money Market Fund of Denver, in 1994. In light of disruptions to the sector in 2008, the SEC is currently reevaluating $2 \mathrm{a}-7$ guidelines and considering the mandating of floating NAVs and the shortening of weighted-average maturities. $^{9}$

\subsection{The Commercial Paper Crisis of September 2008}

Considerable strains in the commercial paper market emerged following the bankruptcy of Lehman Brothers Holdings Inc. on September 15, 2008. Exposure to Lehman forced the Reserve Primary Fund to break the buck on September 16. As a result, money market investors reallocated their funds from prime money market funds to those that held only government securities (Chart 5).

${ }^{9}$ For more details on the money market mutual fund universe and the regulation of 2a-7 funds, see http://www.sec.gov/answers/mfmmkt.htm. 
Chart 5

U.S. Money Market Fund Assets by Fund Type

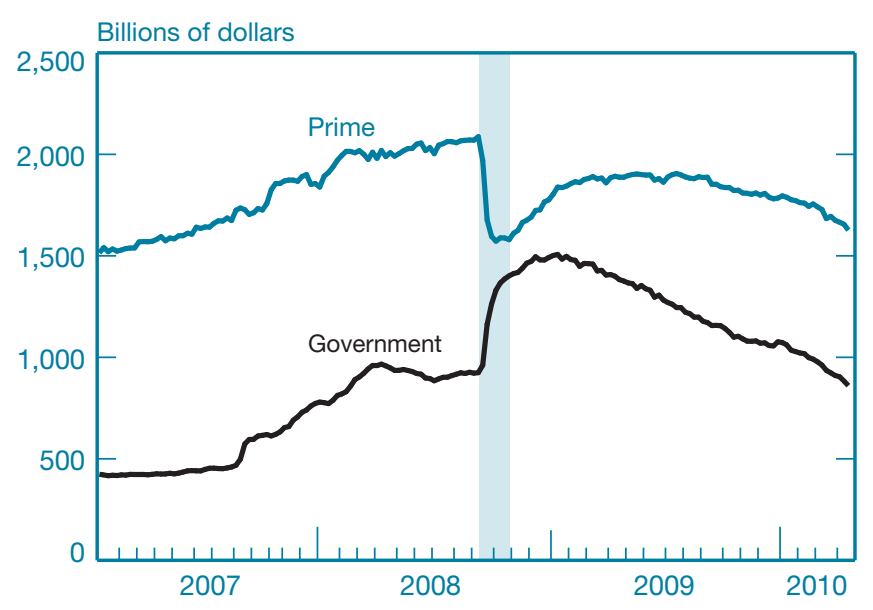

Source: iMoney.

Note: The band denotes September 16-October 21.

This reallocation unleashed a tidal wave of redemption demands that overwhelmed the funds' immediate liquid reserves. In the week following the Lehman bankruptcy, prime money market mutual funds received more than $\$ 117$ billion in redemption requests from investors concerned about losses on presumably safe investments, possible contagion from Lehman's bankruptcy, and financial institutions with large exposures to subprime assets. As a result, 2a-7 money market mutual funds were reluctant, and in some cases unable, to purchase commercial paper (or other money market assets with credit exposure). Any purchases made were concentrated in very short maturities; shortening the duration of their asset holdings made it easier for money market funds to manage uncertainty over further redemptions.

As demand by money market funds shrank, commercial paper issuers were unable to issue term paper and instead issued overnight paper. Thus, with each passing maturity date of commercial paper outstanding, an issuer's rollover risk increased sharply. Banks bore the increasing risk of having their credit lines drawn by issuers unable to place commercial paper in the market precisely when the banks themselves were having difficulty securing funding from the market and were attempting to reduce risk. ${ }^{10}$

More broadly, the deepening dysfunction in the commercial paper market risked greater disruptions across the real economy. The sudden disruption in commercial paper issuance led to higher issuing costs, forced asset sales by entities

\footnotetext{
${ }^{10}$ Commercial banks provide a liquidity backstop for issuers of commercial paper. Rating agencies require that issuers have in place lines of credit in a stipulated percentage of the maximum dollar amount of commercial paper that may be outstanding under the program. See Bond Market Association and Depository Trust and Clearing Corporation (2003).
}

unable to raise cash, resulted in greater insolvency risk among issuers, and increased pressure on credit lines from commercial banks. Together, these factors resulted in reduced credit availability to individuals and businesses generally.

The commercial paper market was vulnerable to the credit, rollover, and liquidity risks that, although small in a period of stable rates and high liquidity, emerged in the wake of the Lehman crisis. Investors averse to credit risk shunned commercial paper issuers that had previously been considered of high quality but were now thought to be candidates for default. Domestic financial paper issuance plummeted 24 percent in late 2008. Likewise, rollover risk-the likelihood that investors will have to be compensated when the issuer rolls over the maturing paper-is magnified when issuers face lack of demand. A combination of liquidity risk and jump-todefault risk was manifested through sharp increases in the rates on A2/P2-rated nonfinancial paper, whose spreads in excess of the overnight index swap (OIS) rate rose from 296 basis points on the Friday prior to Lehman's bankruptcy to 504 basis points one week later. Over the period from September 15 to December 31, the spread averaged 539 basis points. These inherent risks in commercial paper were heightened as money market mutual funds, the principal investors in commercial paper, retreated from this market.

In the month following the Lehman bankruptcy, commercial paper outstanding shrank by $\$ 300$ billion. About 70 percent of this sharp decline was led by the financial commercial paper sector, while 20 percent was attributed to a shrinking of the ABCP market. Notably, the nonfinancial sector was responsible for only a 6 percent retrenchment in the size of total commercial paper outstanding. In the period between the Lehman bankruptcy and the start of the CPFF, total outstanding commercial paper fell sharply, to $\$ 1.5$ trillion from $\$ 1.8$ trillion. By the end of September 2008, more than 75 percent of commercial paper financing was being rolled over each day, leaving the market unusually exposed to additional liquidity shocks.

As rollover risk escalated, institutions relying on commercial paper were increasingly vulnerable to bankruptcy if money market fund investors pulled away from the commercial paper market. Concerned by this growing risk, the Federal Reserve considered ways to stabilize short-term funding markets by providing additional sources of funding to stave off liquidity-driven defaults and help reduce rollover risk.

\subsection{The Federal Reserve's Response}

The CPFF was part of a series of extraordinary policy interventions in late 2008 by the Federal Reserve and other U.S. government agencies. Other important interventions included: 
1. the expansion of eligible collateral for the Primary Dealer Credit Facility (PDCF) and the Term Securities Lending Facility (TSLF) on September 14;

2. the expansion of foreign exchange swap lines with foreign central banks on September 18;

3. the creation, on September 19, of the Asset-Backed Commercial Paper Money Market Mutual Fund Liquidity Facility (AMLF), which extended "nonrecourse loans" (secured loans on which lenders can seize pledged collateral to minimize loss upon default) at the primary credit rate to U.S. depository institutions and bank holding companies to finance their purchases of highquality ABCP from money market mutual funds;

4. the announcement of a temporary guarantee program for money market mutual funds on September 19;

5. the October 14 announcement by the Federal Deposit Insurance Corporation (FDIC) of the creation of the Temporary Liquidity Guarantee Program (TLGP) to guarantee the senior debt of all FDIC-insured institutions and their holding companies as well as deposits in non-interest-bearing deposit transactions;

6. the announcement of the Money Market Investor Funding Facility (MMIFF) on October 21;

7. the creation of the Term Asset-Backed Securities Loan Facility (TALF) on November 25, under which the Federal Reserve Bank of New York was authorized to lend up to $\$ 200$ billion on a nonrecourse basis to holders of AAA-rated ABS and recently originated consumer and small-business loans; and

8. the November 25 announcement by the Federal Reserve that it would purchase the direct obligations of housingrelated government-sponsored enterprises (GSEs) and mortgage-backed securities backed by the GSEs. ${ }^{11}$

\section{CPFF DEsign and Operation}

The Commercial Paper Funding Facility was designed to stabilize short-term financing markets by providing an additional source of funding to institutions to help them reduce reinvestment risk and stave off liquidity-driven defaults. To accomplish this, a special-purpose vehicle-the CPFF LLC — was created to purchase ninety-day commercial

\footnotetext{
${ }^{11}$ See Adrian, Burke, and McAndrews (2009) for more on the PDCF; Fleming, Hrung, and Keane (2009) for details on the TSLF; Davis, McAndrews, and Franklin (2009) for a review of the MMIFF; Ashcraft, Malz, and Pozsar (2010) for more on the TALF; and Adrian and Shin (2010) for an overview of the liquidity facilities in a broader context. The impact of the CPFF and other credit and liquidity programs on the Federal Reserve's balance sheet and its income statement is described at http://www.federalreserve.gov/ monetarypolicy/bst_fedfinancials.htm.
}

paper from highly rated U.S. issuers and effectively pledge it to the Federal Reserve Bank of New York in exchange for cash.

In the twenty days between the announcement of the CPFF and its first purchases from registered users, Federal Reserve staff fine-tuned the facility's terms and conditions and its operational design, which included building a new legal, trading, investment, custodial, and administrative infrastructure as well as establishing essential financial and operational risk controls. For the CPFF to be effective as a liquidity backstop, it had to be simple to use, compliant with existing market conventions, open to a large cross section of the commercial paper market while minimizing credit risk to the Reserve Bank, priced to relieve funding market pressures, and implemented quickly to forestall another liquidity event. The facility's terms and conditions ultimately addressed these objectives. $^{12}$

\subsection{Operational Design}

A market backstop required accessibility by any issuer in the market. However, purchases of commercial paper could not be open to any firm needing access to short-term funding, as this would have deviated from the intent of offering a backstop to issuers whose short-term funding was disrupted by liquidity events rather than the firm's own credit event. To minimize credit risk, the Federal Reserve limited purchases to top-tier paper, rated A1/P1/F1 or higher, consistent with $2 \mathrm{a}-7$ fund conventions in place at the time. ${ }^{13}$ In late 2008, top-tier commercial paper accounted for nearly 90 percent of the market, indicating that the criterion would allow the facility to backstop the vast majority of the market while also shielding the Federal Reserve from lower quality credits in the market.

To effectively reduce rollover risk, the CPFF had to offer term financing beyond what the Federal Reserve had extended up to that point. ${ }^{14}$ Since term commercial paper is most liquid at one- and three-month tenors and funding concerns for the year-end were mounting, three-month commercial paper became the logical tenor to offer issuers. Furthermore, the facility gave assurance that the purchases of commercial paper would be held to maturity rather than liquidated shortly thereafter.

\footnotetext{
${ }^{12}$ For a comprehensive overview of terms and conditions, frequently asked questions, announcements, and operational details relating to the CPFF, see http://www.ny.frb.org/markets/cpff.html.

${ }^{13}$ A split rating was acceptable if two ratings were top-tier.

14 The Fed had already started the twenty-eight-day Term Auction Facility (TAF) in December 2007. On July 30, 2008, an extension to an eighty-four-day maturity was announced, with an effective date of August 11, 2008. For an overview of the TAF, see Armantier, Krieger, and McAndrews (2008).
} 
Issuance to the Commercial Paper Funding Facility (CPFF)

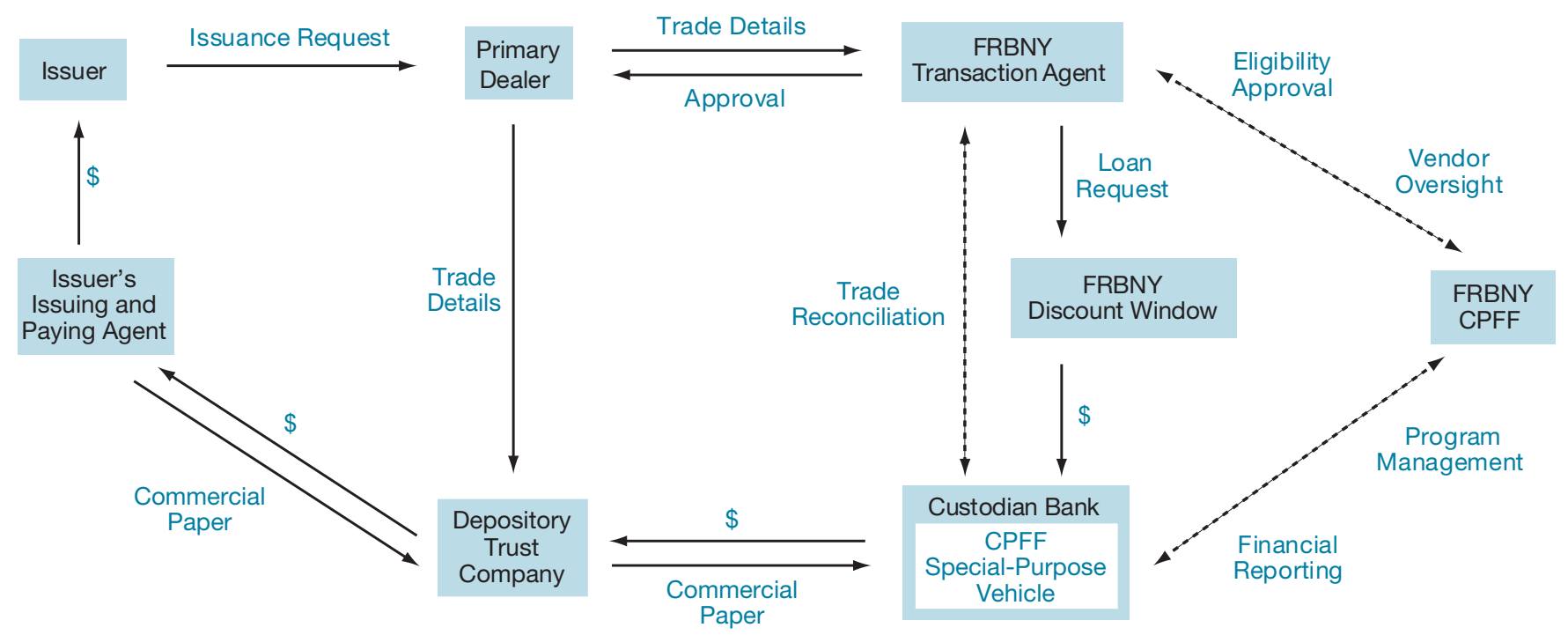

Note: Solid lines represent steps in the transaction; dashed lines represent some of the controls.

In establishing the CPFF, the Federal Reserve faced the added complication of engaging in transactions that fell outside of the central bank's traditional operating framework. Prior to the creation of the CPFF, temporary emergency lending facilities created under section 13(3) of the Federal Reserve Act were forms of secured borrowing with traditional counterparties - that is, depository institutions or primary dealers. To address the risks that had emerged in the commercial paper market, the Federal Reserve had to expand its lending to include U.S. corporations as well as financial institutions that would usually not have direct access to its market operations (finance companies, for example).

The Federal Reserve's financial transactions were limited to open market operations with primary dealers and loans to depository institutions through the discount window. ${ }^{15}$ The CPFF operation married aspects of both types of Fed operations with the market conventions of the commercial paper market. To execute CPFF transactions, the Federal Reserve Bank of New York used its primary dealers as agents to the transactions between the Fed and commercial paper issuers. Primary dealers actively underwrite, place, and make markets in the commercial paper market, and they had the ability to funnel CPFF issuance from their clientele to the facility each day.

By designating primary dealers as agents to the $\mathrm{CPFF}$ transactions, the facility effectively expanded its reach to hundreds of firms looking for backstop financing. Trade execution was conducted electronically, with controls and accuracy checks, and processed "straight through" with limited

\footnotetext{
${ }^{15}$ These included loans of cash and securities as well as purchases and sales of U.S. Treasury and government agency debt.
}

manual intervention, allowing multitudes of trades to be executed quickly and accurately and settled on the same day. The same-day settlement feature assured firms that the CPFF could meet an unexpected liquidity need.

Building the facility's infrastructure in a compressed timeframe proved a substantial challenge, so the Federal Reserve enlisted the services of experienced market participants, including Pacific Investment Management Company (PIMCO) and State Street Bank and Trust Company. The SPV created by the Federal ReserveCPFF LLC—-was held in custody at State Street, a depository institution. Creating the SPV facilitated discount window lending to the commercial paper market. Each day, CPFF purchases were matched by a loan from the New York Fed's discount window to the custodian bank, which then transferred the loan amount to the SVP to fund the purchases.

At maturity, the transaction unwound this way: The issuer paid the CPFF LLC the loan principal plus interest, which was determined by the interest rate set on the date of issuance, and the SPV paid the Federal Reserve Bank of New York the principal and interest on its loan, set at the federal funds target on the original loan date. ${ }^{16}$ Because the custodian bank, the issuing and paying agent (hired by the issuer to administer the issuance of and payments on the commercial paper), and all primary dealers cleared commercial paper through the Depository Trust Company, the CPFF had in place a mechanism that allowed it to purchase commercial paper efficiently through the market's standard clearing institution (see exhibit).

\footnotetext{
${ }^{16}$ If the target federal funds rate was a range, then the loan was set at the
} maximum rate within that range. 


\begin{tabular}{lcc} 
Rates and Fees & Unsecured Commercial Paper & Asset-Backed Commercial Paper \\
\hline $\begin{array}{l}\text { Lending rate } \\
\text { Credit surcharge }\end{array}$ & Three-month OIS +100 basis points & Three-month OIS +300 basis points \\
\multicolumn{1}{c}{ All-in cost } & 100 basis points & None \\
& Three-month OIS +200 basis points & Three-month OIS +300 basis points
\end{tabular}

Source: Federal Reserve Bank of New York.

Note: OIS is the overnight index swap rate.

To sell commercial paper to the CPFF LLC, an issuer was required to register in advance of the initial issuance. ${ }^{17}$ The registration process allowed the Federal Reserve Bank of New York to verify eligibility criteria (including the maximum amount the issuer could sell to the facility), review the issuer's credit quality, and, among other logistics, process the registration fee. While the vast majority of registrants issued to the CPFF shortly after registering, some registered to retain the option of future issuance should the need arise. The CPFF's registration period began on October 20, 2008, one week prior to the first purchase date, to allow time for processing the large number of issuers that wanted the option of issuing to the facility at its inception.

\subsection{The CPFF as Liquidity Backstop}

Eligibility requirements associated with tenor, credit quality, pricing, and maximum issuance were structured to help limit the use of the facility to backstop financing. ${ }^{18}$ Of all these requirements, the facility's pricing structure was the most influential. It was absolutely essential that the rates on CPFF issuance were precisely calibrated to ease financial market stress by offering financing at a rate below the market's extreme levels. At the same time, the Federal Reserve had to ensure that the rates were not too attractive; otherwise, issuers would rely heavily on the CPFF, potentially impairing long-run liquidity and market functioning in the commercial paper market. On October 14, 2008, the Federal Reserve released the pricing structure for the facility (see table).

\footnotetext{
${ }^{17} \mathrm{An}$ "issuer" is the legal entity that issues the commercial paper. If a parent company and a subsidiary issued commercial paper separately, they were considered separate issuers for the purposes of the CPFF. Only U.S. issuers of commercial paper, including U.S. issuers with a foreign parent, were eligible to sell commercial paper to the SPV.

${ }^{18}$ The SPV was allowed to purchase only three-month, U.S.-dollardenominated unsecured and asset-backed commercial paper (rated at least $\mathrm{A} 1 / \mathrm{P} 1 / \mathrm{F} 1$ ) from U.S. issuers or U.S.-based issuers of a foreign parent company. Although split ratings (such that one rating is Tier 2) were accepted, A2/P2 paper-which represents about 5 percent of issuance in the commercial paper market—was ineligible.
}

The facility controlled for changes in short-term interest rates by setting the price of commercial paper issuance to the CPFF at a fixed spread above the daily three-month OIS rate. As is common practice in the market, commercial paper issued to the CPFF was sold at a discount from face value, as determined by the lending rate, using the standard interest calculations and the actual over-360-day-count convention. The all-in costs of the OIS plus 200 and 300 basis points per year on unsecured and asset-backed commercial paper, respectively, were determined after performing historical analysis of several factors, including investment-grade financing rates in recent interest rate cycles, average spreads between unsecured and asset-backed paper, and estimation of potential losses on a diversified portfolio of commercial paper.

The higher funding costs for $\mathrm{ABCP}$ in the market (and in the CPFF pricing structure), relative to unsecured issuance backed by the full faith and credit of the issuing entity, were an indicator of the riskiness and illiquidity of the underlying collateral in $\mathrm{ABCP}$ conduits. In addition to conducting empirical analysis, Federal Reserve staff surveyed a large number of market participants to distinguish between the credit and liquidity components of commercial paper rates at the height of the crisis.

Purchases of commercial paper had to be secured to the satisfaction of the Federal Reserve. Because financial and nonfinancial commercial paper is unsecured, the Fed needed to find alternative means to secure the loans. Although financial institutions could pledge financial assets as collateral against a loan (similar to a discount window transaction), nonfinancial commercial paper issuers would not necessarily have the same privilege. Assessing the value of nonfinancial assets would further complicate lending.

Lenders are generally compensated for taking risk by charging higher interest rates or, in the case of a line of credit, assessing fees on usage. An assessment of a credit surcharge more closely approximated market practice and thus became the default practice for securing a loan. Participation in the FDIC's TLGP qualified as a satisfactory guarantee for unsecured commercial paper, as the U.S. government ensured repayment on the commercial paper at maturity, thus 
removing credit risk. ${ }^{19}$ TLGP issuers were not required to pay the unsecured credit surcharge. As the TLGP was not fully operational on the CPFF's inception date, TLGP issuers were initially charged an unsecured credit surcharge for paper sold to the facility; however, these fees were subsequently reimbursed once it was established that the entity was covered by the TLGP.

The registration fee for the CPFF was an additional feature that further underlined the nature of the facility as a liquidity backstop. The pricing of the registration fee was not dissimilar to a commitment fee that a bank would charge a borrower for an available line of credit. This fee effectively served as an insurance premium, whereby the issuer bought the option of issuing to the facility at any time over the life of the program. The 10 basis point fee was charged on the maximum amount an issuer could sell to the CPFF, or the greatest amount of U.S.-dollar-denominated commercial paper the issuer had outstanding on any day between January 1 and August 31, 2008. The maximum amount of issuance to the CPFF was reduced by any commercial paper outstanding with investors at the time of issuance, including paper issued to the CPFF.

These criteria supported the backstop nature of the facility by limiting issuance to the amount of paper that the institution maintained prior to the market disruptions in September 2008, rather than providing additional funding to grow or leverage issuers' balance sheets. These terms also disqualified firms that were not previously active participants in the commercial paper market from accessing funding through the CPFF. ${ }^{20}$

The CPFF's pricing structure and other program requirements helped ensure that the facility played a constructive role in restoring stability to the market. At the same time, they also served to: 1) prevent artificial inflation of issuance beyond what may be absorbed by investor demand under normal conditions, 2) ensure that the facility was used as a backstop in times of stress while also providing a disincentive to issue to the facility under more liquid market conditions, and 3 ) mitigate the credit risk associated with adverse selection to minimize the Federal Reserve's exposure to loss relative to its accumulated capital from program fees.

\footnotetext{
${ }^{19}$ For each unsecured commercial paper transaction to the CPFF, the issuer was charged 100 basis points per year, calculated from the face value of the commercial paper at the time of settlement. When distributing the proceeds of the new commercial paper issuance, the SPV reduced the funds due the issuer by an amount equal to the unsecured credit surcharge.

${ }^{20} \mathrm{An} \mathrm{ABCP}$ issuer was also deemed inactive if it did not issue $\mathrm{ABCP}$ to institutions other than the sponsoring institution for any consecutive period of three months or longer between January 1 and August 31, 2008. A few months after the facility's inception, the Federal Reserve clarified these terms for ABCP issuers, announcing that the CPFF would not purchase $\mathrm{ABCP}$ from issuers that were inactive prior to the creation of the facility.
}

\subsection{The Fed's Counterparty Credit Risk Management}

From the Federal Reserve's perspective, CPFF lending rates were analogous to setting haircuts on a nonrecourse loan. In setting penalty rates for eligible commercial paper, the Federal Reserve faced a trade-off: Higher penalty rates protect the central bank from credit risk; however, they limit the amount of liquidity available to the financial system.

For a given CPFF interest rate, a rate lower than those available in the market could provide market participants with arbitrage opportunities. In essence, the Federal Reserve lent against specific collateral types_-in this case, highly rated commercial paper - at a penalty rate and held a margin of excess collateral, including cash collateral that should protect it against any loss under normal market conditions.

The anticipated credit risk of the facility's aggregate exposure was an important factor guiding the selection of registration and credit enhancement fees as well as rates for unsecured and asset-backed paper. An initial analysis of the facility's credit risk was conducted to determine ranges of expected and unexpected losses under normal and stressed market conditions. Hypothetical stress losses of 1.03 percent to 1.38 percent were found to reflect historical loss probabilities based on downgrade probabilities of short- and long-term ratings. Any estimated potential credit losses by the CPFF SPV were offset by the facility's invested income from fees and interest received on maturing paper.

In this regard, the cumulative invested income represented the capital available to absorb potential credit losses. The large flow of interest income from the first wave of maturities increased the facility's total capital to more than $\$ 2$ billion, yielding a leverage ratio of nearly 3.4 percent (the leverage ratio is the book value of equity-accumulated through the fee income-divided by the book value of total commercial paper held in the facility). This capital cushion provided a sufficient buffer to absorb the portfolio's stress losses at a 99 percent confidence level, as calculated by a team of New York Fed economists and PIMCO credit analysts. Nevertheless, the facility's credit exposures were more concentrated than a highly granular loan portfolio at a commercial bank, so its ex post loss results could vary significantly from historical loss trends. On February 1, 2010, the date the CPFF expired, the facility had accumulated income in excess of the commercial paper held in the SPV; as a result, no losses were incurred. 


\subsection{Moral Hazard}

The mere existence of a liquidity backstop raises concerns about moral hazard. In the case of the CPFF, expectations that the Fed would act as a lender of last resort and purchase commercial paper could have led issuers to engage in riskier behavior than they otherwise would have. Through its eligibility restrictions, the CPFF was structured to address this possibility of moral hazard.

For example, several months into the program, the eligibility rules were altered to deter the unintended consequence of reviving ABCP conduits that had exited the market. On January 23, 2009, the Federal Reserve announced that the CPFF would not purchase $\mathrm{ABCP}$ from issuers that were inactive prior to the facility's creation. In this way, policymakers sought to limit moral hazard through issuance that no longer had a natural investor base. In addition, the CPFF accepted only paper rated A1/P1. Presumably, issuers that engaged in riskier behavior would risk their top-tier credit rating and, consequently, jeopardize their eligibility for the facility.

Despite these eligibility restrictions, as long as a liquidity backstop exists for an asset market, there will always be some risk that issuers expect liquidity gaps to be filled for higher rated financial and asset-backed commercial paper. One way around this implicit moral hazard would be to publish information on participation with a lag. The attendant cost of such publication, however, is the associated stigma. This creates a risk that the facility will not be used when it is needed most, even in cases where the liquidity risk is broad-based rather than firm-specific.

\subsection{The CPFF's Relation to Other Federal Reserve Liquidity Facilities}

To address the strains in dollar funding markets that emerged immediately after the Primary Reserve Fund "broke the buck," the Federal Reserve introduced, in addition to the CPFF, two other facilities under section 13(3): the Asset-Backed Commercial Paper Money Market Mutual Fund Liquidity Facility and the Money Market Investor Funding Facility. All three facilities supported short-term funding markets and thereby increased the availability of credit through various mechanisms, although the CPFF was used more heavily than the other facilities.

Two factors help explain the CPFF's considerable use. First, the CPFF addressed problems in short-term debt markets at their root-through direct lending to issuers-at a time when issuers faced potential liquidity shortfalls as a result of market dislocations. Indeed, the main factor distinguishing the CPFF from the other two facilities is the CPFF's role as a backstop to issuers, whereas the other facilities provide emergency lending to institutional money market investors. Second, the CPFF backstopped issuance of both unsecured and secured commercial paper, while the AMLF funded only ABCP and the MMIFF special-purpose vehicles purchased only certificates of deposit, bank notes, and commercial paper from specific financial institutions. ${ }^{21}$

While the MMIFF was a liquidity facility for money market mutual funds in the case of abrupt withdrawals by investors, the CPFF effectively bypassed the money market universe by allowing issuers to issue directly into it. Thus, the two facilities addressed slightly different needs.

The AMLF was launched by the Federal Reserve on September 19, 2008. The Federal Reserve Bank of Boston was authorized to make loans to U.S. depository institutions and bank holding companies for the purpose of financing purchases of $\mathrm{ABCP}$ from money market mutual funds. The program specifically sought to help the money market mutual funds facing elevated redemption requests to meet their funding needs. The AMLF operated via a custodian bank, and lending occurred directly through the discount window. Money market mutual funds sold ABCP to their custodian bank, which would subsequently pledge the ABCP to the discount window against a cash loan. The AMLF was made operational in a very short timeframe, because it was much less complex than the CPFF. However, the AMLF accepted only highly rated $\mathrm{ABCP}$, not unsecured commercial paper. AMLF usage peaked on October 8, 2008.

The CPFF, PDCF, TSLF, TALF, and AMLF shared the common features of being liquidity facilities aimed at stabilizing funding in the money markets and being created to counteract the financial market turbulence that threatened the stability of the system as a whole. ${ }^{22}$ Effectively, these facilities extended the Federal Reserve's lender-of-last-resort role to include nondepository institutions (the PDCF, TSLF, and AMLF) and specific securities markets (the CPFF and TALF). The facilities were based on the Federal Reserve's ability to extend credit to "any individual, partnership, or corporation" under "unusual and exigent circumstances," as per section 13(3) of the Federal Reserve Act. ${ }^{23}$

${ }^{21}$ The economic rationale for the MMIFF is described in detail by Davis, McAndrews, and Franklin (2009).

${ }^{22}$ See also the November 18, 2008, testimony of Federal Reserve Chairman Ben Bernanke before the U.S. House of Representatives' Committee on Financial Services on the subject of the Troubled Asset Relief Program and the Federal Reserve's liquidity facilities: http://www.federalreserve.gov/newsevents/ testimony/bernanke20081118a.htm.

${ }^{23}$ For details on the powers of Federal Reserve Banks, see http:// www.federalreserve.gov/aboutthefed/section13.htm. 


\section{CPFF Usage ANd Its Impact ON the Commercial Paper Market}

An issuer's decision to use the CPFF was predicated in part on the cost of issuance to the facility relative to the cost of issuance in the market or other alternative funding sources. As we discussed, the facility's pricing was designed to be cost-effective during times of market stress, but prohibitively expensive during times of normal market function. Accordingly, as conditions in financing markets normalized in 2009, CPFF usage progressively declined.

\subsection{Usage and Market Impact}

The facility's assets grew rapidly at inception, reaching $\$ 144$ billion in the first week of operation. Assets more than doubled, to $\$ 293$ billion, after one month and totaled $\$ 333$ billion by the end of December 2008 (Chart 6). CPFF peak usage occurred in the third week of January 2009, exactly three months after the first issuance date, with approximately $\$ 350$ billion in commercial paper held in the SPV. Throughout 2009, CPFF use steadily declined, reaching a level of around $\$ 10$ billion in December.

At its peak level, the portfolio was primarily composed of financial commercial paper. The portfolio became more and more tilted toward $A B C P$ after the first vintage of the CPFF matured at the end of January 2009. The large share of ABCP in the facility, which continued to increase during 2009, illustrated the continuing difficulties obtaining funding in collateralized money markets.

Issuers to the CPFF included a variety of $\mathrm{ABCP}$ conduitssingle-seller, hybrid, multi-seller, and securities arbitrage conduits-and other financial institutions that conducted banking, insurance, and credit finance in the United States. Issuance trends varied widely across registrants, reflecting the ability of issuers to finance in the market, reduced leverage in the financial system, a consolidation of issuers in the marketplace, and access to other government programs, among other factors. ${ }^{24}$

\footnotetext{
${ }^{24}$ Single-seller conduits are established to fund the assets originated by one seller, or one seller and its subsidiaries and related entities, while multi-seller conduits are structured to fund assets originated by a variety of sellers, typically all clients of the sponsoring commercial bank. Securities arbitrage issuers primarily fund highly rated securities, and investors in the conduits are exposed to the risk of default, or credit risk, of those securities. Hybrid conduits incorporate the structural features of two or more conduit types. Most hybrid conduits have multi-seller and securities arbitrage characteristics. Bate, Bushweller, and Rutan (2003) explain conduits in more detail.
}

Chart 6

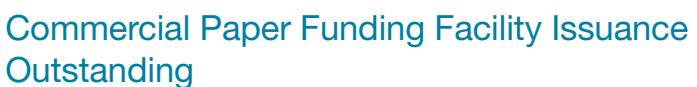

Outstanding

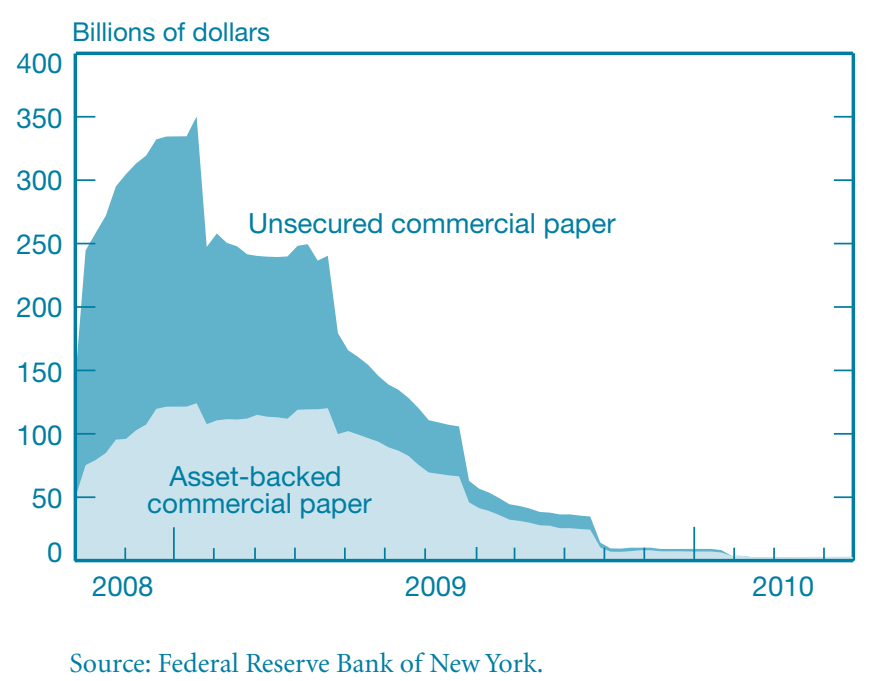

As of December 31, 2009, two-thirds of CPFF holdings were unsecured and the remaining third constituted $\mathrm{ABCP}$. The unsecured paper was issued predominantly by banks and nonbank financials (diversified financials), some of which included TLGP-guaranteed paper. Insurance companies also issued unsecured paper, although to a lesser degree. By the end of 2009, many insurance companies faced losses in light of their exposure to mortgage financing; insurance represented just one of many sectors adversely affected by the financial crisis and economic downturn. Rating agencies subsequently downgraded the commercial paper of several insurance companies, effectively compromising their eligibility for the CPFF.

$\mathrm{ABCP}$ issuance accounted for a growing proportion of assets in the CPFF, suggesting that conduits were having greater difficulty reentering the market and posing some risk of adverse selection in the facility. ABCP conduits were widely used as a means to fund "hard-to-finance" assets. Consequently, it was not surprising to observe a more gradual retrenchment from the facility by this sector. However, $\mathrm{ABCP}$ issuance in the market and in the CPFF declined naturally as assets amortized, securitization slowed, and assets were consolidated to parents' balance sheets. In addition, ABCP programs shrank with changes to regulatory capital requirements and accounting rules.

The CPFF indeed had a stabilizing effect on the commercial paper market, as shown in Chart 7. At its peak in January 2009, the CPFF held more than 20 percent of all outstanding commercial paper. By the time it expired on February 1, 2010, 
Chart 7

Total Commercial Paper Outstanding

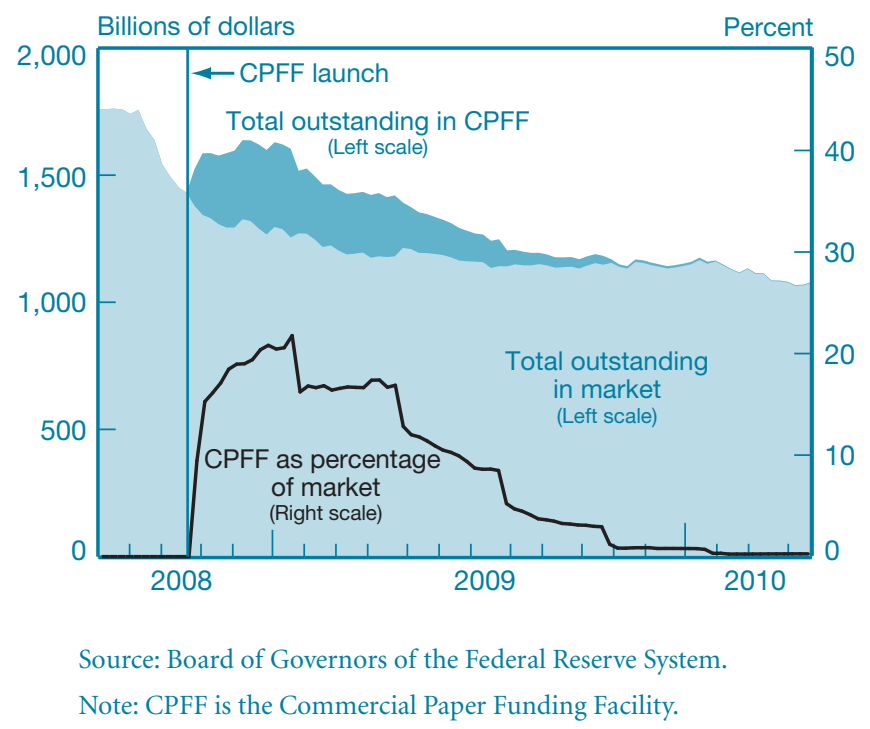

the facility represented only 1 percent of market issuance. The self-liquidating feature of the CPFF is illustrated by the steady decline in the amount of outstanding commercial paper throughout 2009.

During the crisis period after Lehman's bankruptcy and prior to the CPFF's start-up, the fraction of term commercial paper issuance collapsed as money market funds shortened the duration of their assets to ensure against further redemption pressures (see Chart 8). In fact, more than 75 percent of commercial paper issued in the second half of September and in early October consisted of maturities of only one to four days. As a result of the shortened maturities, total weekly commercial paper issuance rose rapidly during the crisis. Once the CPFF started operation on October 27, term commercial paper issuance began rising and quickly reverted to a tight range of between 30 and 40 percent of total commercial paper.

The expansion of the CPFF was accompanied by a narrowing of the spread between commercial paper rates and comparable OIS rates (Chart 9). The degree to which the narrower spread was attributable to the CPFF's expansion requires further research, but the coincidence suggests that the program had a meaningful effect.

The one-month AA-rated financials spread declined from 188 basis points in October 2008 to 38 basis points in December 2009 (the latter being the average of daily business day rates during December). Over the same period, the ABCP spread declined from 256 basis points to 86 basis points. ${ }^{25}$

\footnotetext{
${ }^{25}$ The decline in the less liquid market of three-month commercial paper rates was also substantial. We report the one-month rates because of greater data availability.
}

Chart 8

Weekly Commercial Paper Issuance

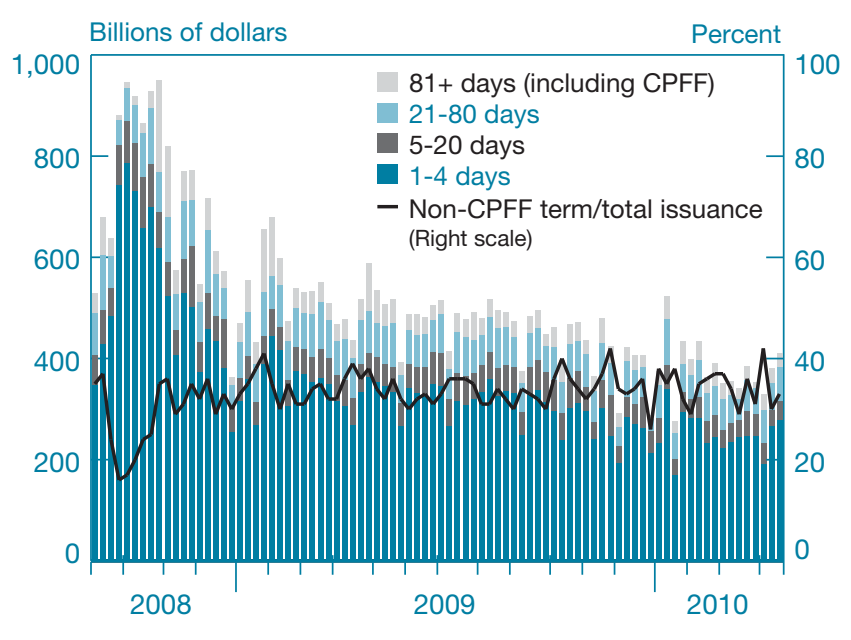

Source: Board of Governors of the Federal Reserve System. Note: CPFF is the Commercial Paper Funding Facility.

Meanwhile, the spread for A2/P2 commercial paper-which was not eligible for the CPFF-rose from 483 basis points to a December average of 503 basis points. The one-month A2/P2 spreads to OIS continued to rise through the end of 2008, as creditors demanded increasing compensation from lower rated issuers for use of their balance sheets over year-end, a period when firms typically reduce leverage for the purpose of financial reporting and minimize risk amid a period of reduced market liquidity. Only after the passage of year-end did the spread between eligible $\mathrm{A} 1 / \mathrm{P} 1$ and ineligible $\mathrm{A} 2 / \mathrm{P} 2$ paper narrow.

The CPFF's holdings rose rapidly in the first three months following the facility's creation, likely because the rates it charged were considerably below the average market rates. As average commercial paper rates began to decline throughout 2009, CPFF usage declined as well.

Average spreads on commercial paper issued in the market (Chart 9) mask the actual cross-sectional dispersion of rates across issuers within each credit rating bucket. The underlying dispersion in rates owes partly to the fact that investors, particularly money market funds, have policies that limit their concentrations to counterparties in order to manage their credit exposure and maintain diversification. As money market funds effectively became more risk averse and attuned to credit differentiation, some funds responded to the financial crisis by either charging higher rates to issuers perceived as potentially more risky or barring certain names altogether from their portfolios.

Continued issuance to the CPFF amid declining commercial paper rates highlighted the wide range of rates transacted in the 
Chart 9

One-Month Commercial Paper Rates Less

One-Month Overnight Index Swap Rate

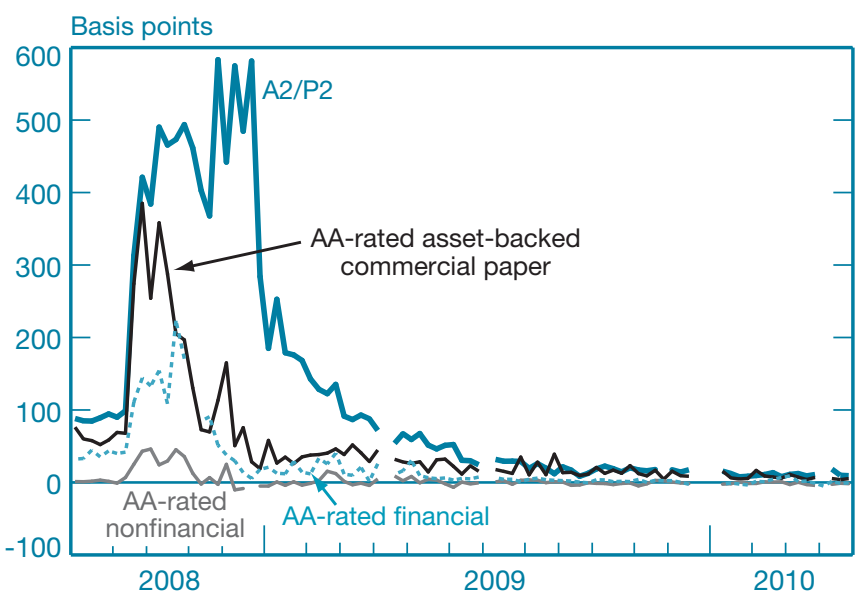

Sources: Board of Governors of the Federal Reserve System; Bloomberg.

market. Although the one-month commercial paper interest rate charged for $A A$-rated $A B C P$ averaged 32 basis points in the second half of 2009 and never exceeded 62 basis points, $\mathrm{ABCP}$ issuance into the CPFF at the penalty rate of 300 basis points (for the three-month maturity) occurred throughout the year, suggesting that some issuers continued to find CPFF rates attractive relative to market rates.

Another possible explanation is that demand for issuance fell short of some issuers' required funding needs. At the onset of the crisis, investors were less willing to hold large positions in commercial paper; thus, issuers may have been left with no option other than to satisfy remaining liquidity needs by issuing to the CPFF.

\section{2. "Roll”}

"Roll" refers to times when issuers retire existing commercial paper at its maturity, but still require funding and therefore issue new paper. In other words, it represents the number of times when commercial paper is reissued, or "rolled over." Because the maturity of CPFF commercial paper was ninety days, rolls occurred once a quarter.

From the beginning of the CPFF to its end, there were five rolls of ninety-day commercial paper. The first roll was the most significant, given that CPFF holdings represented 20 percent of the total commercial paper market. Market analysts had speculated that the still-fragile commercial paper market might come under additional strain if the maturing paper were reissued over a highly concentrated period into the private market. However, the first roll went smoothly, as issuance into the private market remained small and whatever financing returned to the commercial paper or other private markets was relatively dispersed (some issuers prefunded their CPFF maturities and used the proceeds to pay the maturing issuance in the $\mathrm{CPFF}$ ).

Throughout the second and third rolls, an increasing percentage of smaller dollar amounts came due and was paid down. By the fourth roll, in October 2009, approximately 80 percent ( $\$ 28$ billion) of the commercial paper in the CPFF matured, of which roughly $\$ 20$ billion was paid down. As a result, commercial paper holdings in the CPFF amounted to just 1 percent of the total commercial paper market following the penultimate roll.

The most dramatic effect of the rolls was seen in the composition of CPFF holdings. With each roll, ABCP became an even greater share of CPFF holdings as money funds continued to shun secured paper, particularly if it was perceived to be of poor credit quality. Most of the remaining $\mathrm{ABCP}$ may have been of lower credit quality and had no natural buyer. This transformation in CPFF holdings raised policymakers' concerns about adverse selection into the program and about complications that would arise if certain issuers could not have repaid upon the program's conclusion.

\subsection{Impact on the Federal Reserve's Balance Sheet}

Compared with the other new liquidity facilities or with outright purchases, the CPFF had a large effect on the Fed's balance-sheet growth. Only foreign exchange swaps and the TAF made larger contributions. During this period of relatively rapid expansion in assets, the Fed's liabilities expanded primarily through excess reserve balances, although some of the balance-sheet expansion was sterilized by increased issuance of Treasury SFP bills. ${ }^{26}$ While the CPFF contributed to growth in reserves, the contraction in the facility's holdings also outpaced that of other Federal Reserve programs, given its punitive rate structure. This contraction significantly offset the reserves creation of later programs, such as the Large-Scale Asset Purchase Program. ${ }^{27}$

\footnotetext{
${ }^{26}$ On September 17, 2008, the U.S. Treasury announced the Supplementary Financing Program (SFP), through which the Treasury issues a series of Treasury bills, separate from its current borrowing program, and deposits the proceeds from these issuances into an account at the Federal Reserve Bank of New York. Funds in this account drain reserves from the banking system and therefore offset the reserve impact of Federal Reserve lending and liquidity initiatives. Interest on reserves is discussed in Keister and McAndrews (2009).

${ }^{27}$ The impact of the CPFF and other credit and liquidity programs on the Federal Reserve's balance sheet and income statement can be found at http:// www.federalreserve.gov/monetarypolicy/bst_fedfinancials.htm.
} 
The CPFF's penalty fee represented income for the Federal Reserve. The facility generated roughly $\$ 5$ billion in net income from its inception to its close in April 2010. This amount represented a relatively large share of total profits from the liquidity facilities, estimated to be $\$ 12.9$ billion as of December 2009 (Fleming and Klagge 2009). These profits, which were transferred by the Federal Reserve to the Treasury, ultimately helped reduce the financial burden on taxpayers.

The economic interpretation for the income generated by the CPFF is as follows. During fall 2008, the private market for commercial paper was severely disrupted by the reallocation of short-term savings from prime money market funds to Treasury-only funds. As a result, the Federal Reserve established the CPFF as a lender-of-last-resort facility to address the temporary liquidity distortions created by the money market reallocations. However, by law, the Federal Reserve had to protect itself against potential credit losses. It therefore loaned to commercial paper issuers at a penalty rate, which in turn generated income from the facility.

While market rates for commercial paper were unusually high, commercial paper issuers were willing to pay the penalty rate, thereby transferring money to the taxpayer. As such, U.S. households gained in the aggregate. In addition to the fee income generated by the CPFF, taxpayers also benefited from the facility's role in potentially preventing commercial paper issuers from being forced into bankruptcy, an event that could have distorted real investment decisions.

\section{Conclusion}

The Commercial Paper Funding Facility serves as a noteworthy model for the Federal Reserve's role as lender of last resort-a role that, in this case, reached beyond depository institutions. In contrast to traditional discount window lending, the CPFF supported liquidity in a particular market as opposed to supporting the liquidity of a particular set of institutions. Like the discount window, the CPFF was constructed as a backstop, not as a permanent source of funding. While the discount window accepts a very broad range of collateral_-including loans, mortgages, and securities-the CPFF focused on a particular asset class, but had less stringent requirements for the types of institutions that can borrow. The CPFF can be considered a model of liquidity provision in a market-based financial system, where maturity transformation occurs outside of the commercial banking sector in a quantitatively and economically important magnitude.
The legal basis for the CPFF stemmed from section 13(3) of the Federal Reserve Act, requiring the use of such a facility in "unusual and exigent circumstances." As such, the Federal Reserve does not have the authority to make the CPFF a permanent liquidity backstop. This in turn has implications for the ongoing debate on regulatory reform. The financial market crisis of 2007-09 demonstrated the current financial architecture's vulnerabilities to liquidity crises emanating from nondepository institutions. As such, an important component of regulatory reform focuses on improving the resiliency of money markets to financial and economic shocks. Many ongoing reform efforts aim to reduce the vulnerability of money markets to liquidity crises. These efforts focus particularly on reforming money market funds, the commercial paper market, and the repo markets.

It has long been understood that the public sector plays a crucial role in the provision of liquidity. In times of aggregate liquidity shortages, only the monetary authority can act as lender of last resort, owing to its ability to create money. ${ }^{28}$ Traditionally, the lender of last resort has been available only to depository institutions because the vast majority of maturity and liquidity transformation took place in those institutions. Since the mid-1980s, however, the rapid growth of a marketbased system of credit formation has allowed for maturity transformation by a wide range of institutions, including money market funds, finance companies, and securities broker-dealers, and through a range of market instruments, such as asset-backed commercial paper and tri-party repo.

Despite the recent crisis, it seems likely that large amounts of maturity and liquidity transformation will continue to be conducted outside of depository institutions - and therefore without access to the traditional lender of last resort-in what is known as "the shadow banking system." ${ }^{29}$ The public sector's role in providing backstop liquidity to the shadow banking system will continue to be debated. Although the duration of the CPFF was necessarily limited, the facility provides a model for a market-based lender-of-last-resort liquidity backstop, which could serve as a guide for future policy discussion.

${ }^{28}$ See Holmström and Tirole (1998) for a theory of public liquidity provision, Diamond and Dybvig (1983) for a classic justification of discount window lending, and Acharya, Gale, and Yorulmazer (2008) for a setting with rollover risk.

${ }^{29}$ Adrian, Ashcraft, and Pozsar (2009) provide a detailed overview of the shadow banking system. 


\section{REFERENCES}

Acharya, V., D. Gale, and T. Yorulmazer. 2008. "Rollover Risk and Market Freezes.” Unpublished paper, New York University and Federal Reserve Bank of New York.

Acharya, V., and P. Schnabl. 2010. "Securitization without Risk Transfer.” Unpublished paper, New York University.

Adrian, T., A. Ashcraft, and Z. Pozsar. 2009. "Shadow Banking." Unpublished paper, Federal Reserve Bank of New York.

Adrian, T., C. R. Burke, and J. J. McAndrews. 2009. "The Federal Reserve's Primary Dealer Credit Facility." Federal Reserve Bank of New York Current Issues in Economics And Finance 15, no. 4, August.

Adrian, T., and H. S. Shin. 2010. "The Changing Nature of Financial Intermediation and the Financial Crisis of 2007-2009.” Federal Reserve Bank of New York Staff Reports, no. 439, March.

Armantier, O., S. Krieger, and J. McAndrews. 2008. "The Federal Reserve's Term Auction Facility.” Federal Reserve Bank of New York Current Issues in Economics and Finance 15, no. 5, July.

Ashcraft, A., A. Malz, and Z. Pozsar. 2010. “The Federal Reserve's Term Asset-Backed Securities Loan Facility.” Unpublished paper, Federal Reserve Bank of New York.

Bate, S., S. Bushweller, and E. Rutan. 2003. "The Fundamentals of Asset-Backed Commercial Paper.” Moody's Investors Service Structured Finance Special Report, February 3.

Bond Market Association and Depository Trust and Clearing Corporation. 2003. "Issues and Recommendations Regarding Commercial Paper Settlement Practices.” White paper, March 3.
Covitz, D. M., N. Liang, and G. A. Suarez. 2009. "The Evolution of a Financial Crisis: Panic in the Asset-Backed Commercial Paper Market.” Board of Governors of the Federal Reserve System Finance And Economics Discussion Series, no. 2009-36, September.

Davis, J., J. McAndrews, and K. Franklin. 2009. “The Money Market Investor Funding Facility.” Unpublished paper, Federal Reserve Bank of New York.

Diamond, D. W., and P. H. Dybvig. 1983. "Bank Runs, Deposit Insurance, and Liquidity.” Journal of Political Economy 91, no. 3 (June): 401-19.

Fleming, M. J., W. B. Hrung, and F. M. Keane. 2009. "The Term Securities Lending Facility: Origin, Design, and Effects.” Federal Reserve Bank of New York Current Issues in Economics AND FinANCE 15, no. 2, February.

Fleming, M. J., and N. Klagge. 2009. "Income Effects of Federal Reserve Liquidity Facilities.” Unpublished paper, Federal Reserve Bank of New York.

Holmström, B., and J. Tirole. 1998. "Private and Public Supply of Liquidity." Journal of Political Economy 106, no. 1 (February): 1-40.

Keister, T., and J. McAndrews. 2009. "Why Are Banks Holding So Many Excess Reserves?” Federal Reserve Bank of New York Staff Reports, no. 380, July.

The views expressed are those of the authors and do not necessarily reflect the position of the Federal Reserve Bank of New York or the Federal Reserve System. The Federal Reserve Bank of New York provides no warranty, express or implied, as to the accuracy, timeliness, completeness, merchantability, or fitness for any particular purpose of any information contained in documents produced and provided by the Federal Reserve Bank of New York in any form or manner whatsoever. 